\title{
55. スキャノグラムを用いた放射線治療計画の精度
}

Acuracy of radiotherapy treatment planning using CT-scanogram

$\begin{array}{ccc}\text { 国立がんセンター東病院 } \begin{array}{c}\text { ○藤川弘幸 } \\ \text { Hiroyuki Fujikawa } \\ \text { 斎藤裕久 } \\ \text { Yasuhisa Saitoh }\end{array} & \begin{array}{c}\text { 久保田忠幸 } \\ \text { Tadayuki Kubota } \\ \text { 荻野 尚 }\end{array} & \begin{array}{c}\text { 沼野真澄 } \\ \text { Masumi Numano }\end{array} \\ & \text { Takashi Ogino } & \end{array}$

X 線 CT 画像は治療計画に必須となっている。今回我々は CT スキャ ノグラム上で決定した標的を評価し、高精度の治療計画、治療の補助手 段としての報告をする。

【目的】1.CT スキャノグラムを用いて、作成した照射野について実際 の大きさと照射野中心との差を比較検討する。2．CT スキャノグラム像 での治療計画とX線シミュレータとのズレを検討することを目的とした。 【方法】照射中心をスキャノグラム像中央に設定し，方眼紙上に点をプ ロットして $4 \times 4 \mathrm{~cm}$ から $16 \times 16 \mathrm{~cm}$ の照射野を作り誛台の高さによるこ の照射野の大きさの変化を見た。

治療計画ソフト CT-Portを用いスキャノグラム上に照射野を書きX線シ ミュレータでスキャノ計画を再現し相互の照射野中心の差を計測した。

【結果】寝台が高くなるにつれて実際の照射野幅が大きくなり、逆に低 くなると小さくなる。又、照射野が大きくなるにしたがい実際の大きさ より差が大きくなる(Fig.1)。これはスキャノグラムの X 方向で外側一行 くにしたがい流れる度合いが高くなっているためである。Axial 画像中 心部においては画像補正しているためズレは生じない。このグラフはス キャノグラム X 軸方向に $10 \mathrm{~cm}$ 移動し前項と同じ実験をした結果である。 (Fig.2)上部のグラフは照射野幅の変化を意味する。照射野縦の変化はほ とんどなく寝台の高さを変えるとスキャノグラム上照射中心の横座標の ズレのみが生ずる。臨症例でも対象は椎骨転移 頚椎 2 症例，胸椎 9 症 例 腰椎 10 症例で行った。横軸のデプス 0 とは Axial 画像 X 軸中心を いいそこからの距離を横軸にとり、又縦軸の差は絶対值として表してい る。(Fig.3)

【線錘の表示.調整】この症例は当院の治療計画ソフトCT-Port で照射野 を作成したものである。スキャノグラム像に第 5 腰椎中心に照射野を設 定したものであり Axial 像骨破壊を伴う mass がありはみだしている。 CT-Port では線錘微調整機能があり線鍾を変更可能である。それがスキ ヤノグラム像の照射野として反映する。線鍾微調整機能は Axial スライ ス毎に変更可能である。 $100 \times 90 \mathrm{~mm}$ の照射野が線錘を調整することに より massを含んだ照射野内におさまっている。(Fig.4)

【結語】スキャノ画像を用いた放射線治療計画においてターゲット中心 による補正を行わない場合の照射野の大きさ、および照射中心のズレを グラフ化し把握した。

Axiai 面でのズレは線錘表示により確認でき線錘微調整機能で対応可 能であり腫瘍及び正常組織の正確な位置が確認できその結果放射線治療 計画の補助が可能となった。側面スキャノ像での線錘表示は X 線シミュ レータの感覚での計画を可能にした。

臨症例でも、照射中心のズレは平均で X 方向 $1.59 \mathrm{~mm} 、 \mathrm{Y}$ 方向 $1.57 \mathrm{~mm}$ であり最大でも $3.5 \mathrm{~mm}$ であった。これは、患者の体動・共用寝台の精度 が含まれており CT スキャノ画像での治療計画は可能と考えられた。
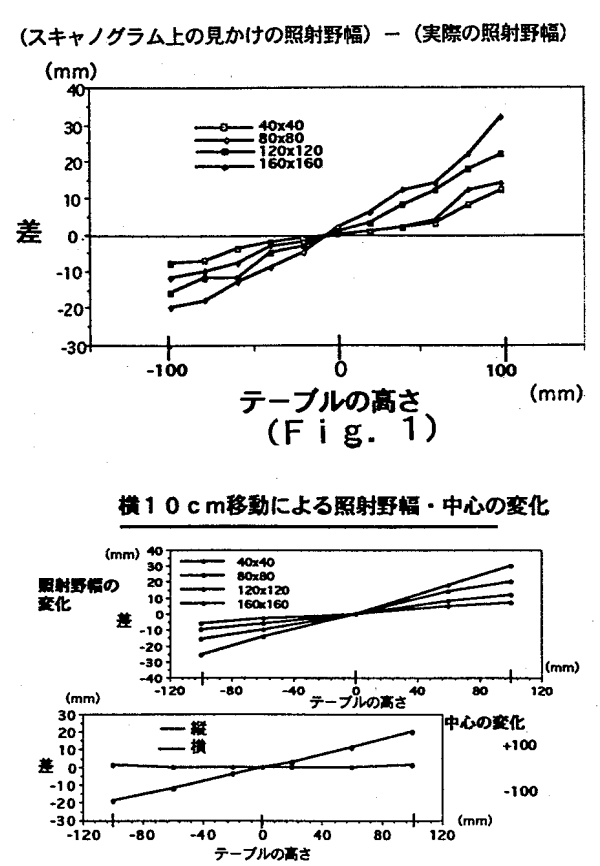

(F i g. 2)

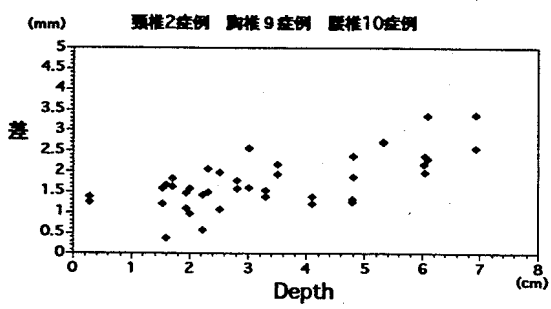

(F i g. 3)
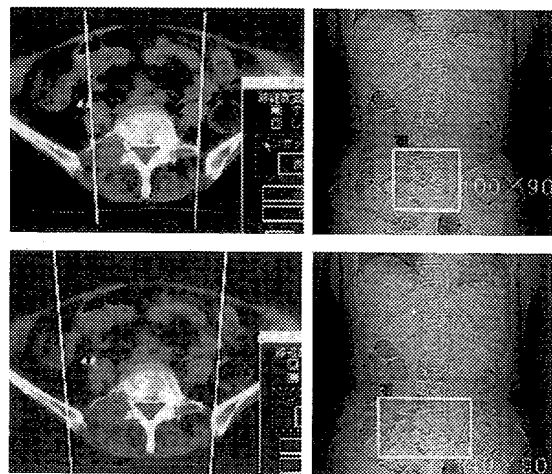

(F i g. 4)

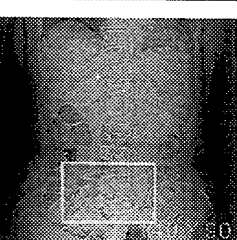

4) 